\title{
Short Communication: Genetic polymorphism of registered and popularly cultivated coffee (Coffea spp.) in the Philippines using inter-simple sequence repeats markers
}

\author{
ARLEEN C. PANALIGAN ${ }^{1,2, \boldsymbol{v}}$, MIRIAM D. BALTAZAR ${ }^{2,3}$, GRECEBIO JONATHAN D. ALEJANDRO ${ }^{1,4}$ \\ ${ }^{1}$ Graduate School, University of Santo Tomas. España 1015, Manila, Philippines \\ ${ }^{2}$ Department of Biological Sciences, Cavite State University. Indang 4122, Cavite, Philippines. Tel. +63-917-3980831, `email: acpanaligan@ cvsu.edu.ph \\ ${ }^{3}$ National Coffee Research, Development and Extension Center, Cavite State University. Indang 4122, Cavite, Philippines \\ ${ }^{4}$ College of Science and Research Centre for the Natural and Applied Sciences, University of Santo Tomas. España 1015, Manila, Philippines
}

Manuscript received: 7 June 2020. Revision accepted: 22 August 2020.

\begin{abstract}
Panaligan AC, Baltazar MD, Alejandro GJD. 2020. Short Communication: Genetic polymorphism of registered and popularly cultivated coffee (Coffea spp.) in the Philippines using inter-simple sequence repeats markers. Biodiversitas 21: 4228-4233. Three Coffea species, namely Coffea arabica, Coffea canephora and Coffea liberica have been commercially cultivated in the Philippines. Genetic variability analysis of these species is important for the conservation of genetic resources and breeding programs. Hence, this study was carried out to identify polymorphic inter-simple sequence repeats (ISSR) markers and determine the genetic variation of these three commercially cultivated coffee species. Twenty-nine DNA samples from young coffee leaves were extracted and PCR amplified. Of the 29 primers used, seven produced clear and reproducible bands. In the 54 bands produced, 51 were polymorphic. The number of bands amplified by each primer varied from 5 to 12 with an average of 7.71 bands. Polymorphism percentage ranged from 80 to 100 . This is the first time that ISSR markers were used to determine the genetic variation of coffee in the Philippines. The study demonstrated the efficiency of ISSR markers to assess genetic variation in cultivated coffee species. The ISSR markers were able to differentiate the coffee germplasm at the interspecific and intraspecific levels. These results suggest the potential of ISSR markers for genetic diversity analysis of commercial coffee and varietal identification of elite varieties using DNA fingerprinting.
\end{abstract}

Keywords: Arabica, genetic diversity, ISSR, Kapeng Barako, robusta

\section{INTRODUCTION}

Coffee (Coffea spp.) belongs to the Rubiaceae family which is composed of 124 species (Davis et al. 2011). In the Philippines, there are three commercially cultivated species, namely Coffea arabica L., Coffea canephora Pierre ex Froehner, and Coffea liberica W. Bull ex Hiern. Philippines is one of the few countries that propagates these three coffee species for commercial consumption. In most countries, only Coffea arabica and Coffea canephora are of high commercial value (International Coffee Organization 2018), while Coffea liberica is used only as grafting rootstock for Coffea arabica and Coffea canephora (Davis et al. 2019).

Genetic diversity analysis of Coffea species is important for the conservation of genetic resources and breeding programs. Hence, various techniques have been used to evaluate the genetic variation of Coffea species. One method which is morphological characterization, is based on visible traits such as fruit size and leaf margin. Morphological characterization is simple and does not involve expensive equipment and chemicals, but morphological data are influenced by the environment and plant life stages. Moreover, morphological characters of some coffee individuals have been observed to be overlapping even at the matured stage, when they are already bearing flowers and fruits. As an example, Anagbogu et al. (2019) reported that previous morphological characterizations of Coffea canephora in Nigeria were inconclusive. An accession formerly classified as Coffea liberica based on morphology was revealed as a Coffea canephora by using molecular marker. Another method which is, biochemical analysis, uses isozymes. It requires only minute amounts of biological substances but the availability of enzyme markers is limited (Govindaraj et al. 2015). Unlike morphological and biochemical techniques, molecular markers are numerous and are not dependent on the environment and plant stages.

Some commonly used DNA-based techniques for genetic variation analysis of Coffea species include random amplified polymorphic DNA (RAPD), amplified fragment length polymorphism (AFLP), simple sequence repeats (SSR) and inter-simple sequence repeats (ISSR). Some previous studies, compared such techniques and reported some advantages and limitations (Kayis et al. 2010; Ferrao et al. 2013; Garriga et al. 2013; Lal et al. 2014). Amplified fragment length polymorphism has high polymorphism as compared to SSR and RAPD but it is labor-intensive, requires more resources, and difficult to interpret (Ferrao et al. 2013). Another technique is the utilization of ISSR markers, which is economical, highly efficient in 
generating polymorphism of closely related varieties, more reproducible than RAPD, and can be used as an alternative to SSR (Kayis et al. 2010; Garriga et al. 2013). In some cases, ISSR markers, which are dominant, generated more polymorphism than when using RAPD and SSR (Lal et al. 2014). Inter-simple sequence repeats had been used to evaluate the genome group and genetic variability of some economically important crops (Aguilera et al. 2011; Carrasco et al. 2012; Esmailnia et al. 2015; Raghavendra et al. 2016; Wahyudi et al. 2020). However, there have been no reports on genetic diversity analysis of coffee using ISSR in the Philippines. Thus, this study aims to identify polymorphic ISSR markers and to determine the genetic variation of registered and popularly cultivated coffee species in the Philippines.

\section{MATERIALS AND METHODS}

\section{Plant materials}

Twenty-nine samples representing three Coffea species, i.e. Coffea arabica (9 samples), Coffea canephora (9 samples), and Coffea liberica (11 samples) were collected from government and private institutions in the Philippines. The registered samples were verified by the Bureau of Plant Industry (BPI) while the other samples were identified by the coffee growers. Young fresh leaves were collected and placed individually in zip-lock bags with silica gel for DNA extraction. The Coffea samples used in this study are listed in Table 1.

\section{DNA extraction}

Genomic DNA samples were extracted from silicadried coffee leaves using the Dneasy Plant Mini Kit (Qiagen, Germany) according to the manufacturer's protocol. The quality and quantity of the extracted DNA were estimated using lambda $(\lambda)$ DNA as standard (Grativol et al. 2010) in 1\% agarose gel (Wahyudi et al. 2020).

\section{Screening of primers and amplification of ISSR markers}

Twenty-nine primers from published journal articles were screened for polymorphism. Polymerase chain reaction (PCR) was performed at least twice for all the samples to evaluate the reproducibility of the ISSR markers. The PCR reaction was performed according to the protocol described by Mishra et al. (2011) with some modifications. The PCR mixture for each marker was prepared with a total volume of $10 \mu \mathrm{L}$ per reaction containing $1 \times$ reaction buffer $(500 \mathrm{mM} \mathrm{KCl}, 100 \mathrm{mM}$ Tris$\mathrm{HCl}$ pH 9.1, 0.1\% Triton X-100), 10 ng DNA, $0.2 \mathrm{mM}$ dNTP mixture, $2.5 \mathrm{mM} \mathrm{MgCl} 2,0.4 \mu \mathrm{M}$ primer (Table 2) and $0.5 \mathrm{U}$ Taq DNA polymerase.

Table 1. List of Coffea samples used in this study

\begin{tabular}{|c|c|c|c|}
\hline Code & Species & Local Name & Place of collection \\
\hline 1 & Coffea arabica & Typica & Ampasit, La Trinidad, Benguet \\
\hline 2 & Coffea arabica & Granica Standard & BSU, Ampasit, La Trinidad, Benguet \\
\hline 3 & Coffea arabica & Yellow Caturra & BSU, Ampasit, La Trinidad, Benguet \\
\hline 4 & Coffea arabica & Mundo Novo (Ampasit) & BSU, Ampasit, La Trinidad, Benguet \\
\hline 5 & Coffea arabica & Red Bourbon & Atok, Benguet \\
\hline 6 & Coffea arabica & Mysore T’boli & Polomolok, South Cotabato \\
\hline 7 & Coffea arabica & Yellow Bourbon & Bureau of Plant Industry (BPI), Baguio City \\
\hline 8 & Coffea arabica & Red Caturra & BPI, Baguio City \\
\hline 9 & Coffea arabica & RDRF Arabica & Los Baños, Laguna \\
\hline 10 & Coffea canephora & FRT 7 & NOMIARC, Bukidnon \\
\hline 11 & Coffea canephora & FRT 11 & NOMIARC, Bukidnon \\
\hline 12 & Coffea canephora & FRT 23 & NOMIARC, Bukidnon \\
\hline 13 & Coffea canephora & FRT 65 & NOMIARC, Bukidnon \\
\hline 14 & Coffea canephora & CvSU NSIC Robusta & Indang, Cavite \\
\hline 15 & Coffea canephora & Robusta 1 & Alfonso, Cavite \\
\hline 16 & Coffea canephora & Robusta 2 & Indang, Cavite \\
\hline 17 & Coffea canephora & Robusta 3 & Indang, Cavite \\
\hline 18 & Coffea canephora & Robusta 4 & Indang, Cavite \\
\hline 19 & Coffea liberica & BS1 & Indang, Cavite \\
\hline 20 & Coffea liberica & BS2 & Indang, Cavite \\
\hline 21 & Coffea liberica & Calaboso Liberica & Tagaytay, Cavite \\
\hline 22 & Coffea liberica & Calanog Liberica & Silang, Cavite \\
\hline 23 & Coffea liberica & CvSU NSIC Liberica & Indang, Cavite \\
\hline 24 & Coffea liberica & NCRDEC Liberica & Indang, Cavite \\
\hline 25 & Coffea liberica & Alfonso Liberica & Alfonso, Cavite \\
\hline 26 & Coffea liberica & Excelsa 1 & Indang, Cavite \\
\hline 27 & Coffea liberica & Excelsa 2 & Indang, Cavite \\
\hline 28 & Coffea liberica & Excelsa 3 & Indang, Cavite \\
\hline 29 & Coffea liberica & Excelsa 4 & Indang, Cavite \\
\hline
\end{tabular}


Table 2. Polymorphism generated by ISSR analysis in Coffea species

\begin{tabular}{|c|c|c|c|c|c|c|}
\hline Primer & $\begin{array}{l}\text { Sequence } \\
\text { (5' to 3') }\end{array}$ & $\begin{array}{l}\text { Total no. } \\
\text { of bands }\end{array}$ & $\begin{array}{l}\text { No. of polymorphic } \\
\text { bands }\end{array}$ & $\begin{array}{c}\text { Polymorphism } \\
(\%)\end{array}$ & PIC & $\mathbf{R p}$ \\
\hline UBC 810 & $(\mathrm{GA})_{8} \mathrm{~T}$ & 6 & 6 & 100 & 0.500 & 2.21 \\
\hline UBC 811 & $(\mathrm{GA})_{8} \mathrm{C}$ & 8 & 7 & 87.5 & 0.440 & 2.68 \\
\hline UBC 826 & $(\mathrm{AC})_{8} \mathrm{C}$ & 12 & 12 & 100 & 0.430 & 5.24 \\
\hline UBC 834 & $(\mathrm{AG})_{8} \mathrm{YT}$ & 10 & 10 & 100 & 0.430 & 3.65 \\
\hline UBC 835 & $(\mathrm{AG})_{8} \mathrm{YC}$ & 5 & 4 & 80.0 & 0.460 & 1.65 \\
\hline UBC 836 & $(\mathrm{AG})_{8} \mathrm{YA}$ & 8 & 8 & 100 & 0.490 & 4.07 \\
\hline UBC 841 & $(\mathrm{GA})_{8} \mathrm{YC}$ & 5 & 4 & 80.0 & 0.460 & 0.89 \\
\hline Total & & 54 & 51 & & 3.210 & 20.4 \\
\hline Mean & & 7.71 & 7.29 & 92.5 & 0.460 & 2.91 \\
\hline
\end{tabular}

Note: PIC: polymorphic information content; Rp: resolving power

The PCR condition was set with an initial denaturation at $95^{\circ} \mathrm{C}$ for $3 \mathrm{~min}$, followed by 30 cycles of denaturation at $94^{\circ} \mathrm{C}$ for $1 \mathrm{~min}$, annealing at $60^{\circ} \mathrm{C}$ for $90 \mathrm{~s}$, extension at $72^{\circ} \mathrm{C}$ for $2 \mathrm{~min}$, and a final extension at $72^{\circ} \mathrm{C}$ for $10 \mathrm{~min}$, using a T100 Thermal Cycler (Bio-Rad). PCR products were run on $1.5 \%$ agarose gels containing Biotin Gel Red $^{\mathrm{TM}}$ DNA stain in $1 \times$ TAE buffer at $80 \mathrm{~V}$ for two hours using Labnet ENDURO ${ }^{\mathrm{TM}}$ Horizontal Gel Electrophoresis, and were visualized and photographed using Bio-Print ST4 Vilber Lourmat Gel Documentation System.

\section{Scoring of bands and analysis of genetic variability}

Polymorphic markers were scored for the presence (1) or absence $(0)$ of clear and reproducible amplified DNA fragments. The total number, polymorphic, and average number of bands per primer were computed. Each primer was assessed using polymorphic information content (PIC) and resolving power ( $\mathrm{Rp})$. The PIC was computed as PIC = $2 \mathrm{fi}$ (1-fi), where fi is the frequency of amplified allele (band present) and 1-fi is the frequency of null allele (band absent) (Roldán-Ruiz et al. 2000). The resolving power (Rp) of each primer was calculated as $\Sigma \mathrm{I}_{\mathrm{b}}$, where $\mathrm{I}_{\mathrm{b}}$ (band informativeness) was computed as $\mathrm{I}_{\mathrm{b}}=1-[2 \mathrm{x}(0.5-\mathrm{p})]$, where $\mathrm{p}$ is the ratio of the 29 coffee individuals sharing the band (Prevost and Wilkinson 1999).

Jaccard's similarity coefficients were calculated using Numerical Taxonomy and Multivariate Analysis (NTSYS PC) version 2.0 software Unweighted Pair Group Method with Arithmetic Mean (UPGMA) using sequential, agglomerative, hierarchical and nested clustering algorithm (SAHN) was used to analyze the relationships of the 29 coffee accessions (Rohlf 2000). PAST (Paleontological Statistical) software was used for the Principal Coordinates Analysis (PCoA) (Hammer et al. 2001).

\section{RESULTS AND DISCUSSION}

\section{Genetic variability of Coffea spp.}

Of the 29 primers screened, seven (24\%) produced clear and reproducible DNA fragments, and generated a total of 54 bands, of which $51(94.44 \%)$ were polymorphic. The number of bands amplified by each primer ranged from 5 to 12 with an average of 7.71 (Table 2). Polymorphism percentage of the ISSR markers ranged from 80 to 100 . Of the seven primers, four (UBC 810, UBC 826, UBC 834, and UBC 836) showed $100 \%$ polymorphism. The average polymorphism percentage of 92.5 was comparable with the result of Mishra et al. (2011) which was 91.3.

The efficiency of ISSR markers was evaluated using PIC (polymorphic information content) and Rp (resolving power). Polymorphic information content refers to the value of a marker for detecting the degree of polymorphism. In this study, the PIC values ranging from 0.43-0.50 with an average of 0.46 indicate that the ISSR markers used were informative and they could be used in genetic diversity studies on cultivated coffee. The result of this study is incomparable with the result of Mishra et al. (2011) because the high average PIC (0.83) may be attributed to the wide genetic variation of their indigenous coffee species sampled from wild habitat. Resolving power (Rp) measures the discriminatory power of ISSR markers. In this study, the Rp ranged from 0.89 (UBC 841) to 5.24 (UBC 826) with an average of 2.91. Prevost and Wilkinson (1999) reported that the Rp of hypothetical primers and the percentage of discriminated potato cultivars had a strong linear relationship. However, this relationship was not observed in the study of Mishra et al. (2011). For instance, UBC 835 and UBC 840 had 100\% polymorphism and had the highest PIC but they did not have the highest Rp. On the other hand, UBC 881 had the lowest PIC and yet it had the highest resolving power. UBC 880 did not have the highest PIC and Rp but it was the only primer that was able to discriminate most of the species. The ISSR markers used in this study may be considered for fingerprinting of cultivated coffee and evaluate the relationship between PIC and $\mathrm{Rp}$.

\section{Genetic relationship and clustering analysis}

The Jaccard's similarity coefficients of the three Coffea species varied from 0.19 to 1.00. Among Coffea arabica, the genetic similarity ranged from 0.50 to 1.0. Typica (code 1) and Yellow Caturra (code 3), had no variation (Table 3 and Figure 1) which could be due to any of the following: (i) labelling errors in the collection of samples; (ii) seedling 
management; (iii) establishment in the field. Seedling collection and management practices could be evaluated, and necessary adjustments could be carried out when needed, to avoid possible errors. Excluding the two, Red Bourbon (code 5) and Yellow Bourbon (code 7) had the highest genetic similarity (0.95). Red Caturra (code 8) and Mundo Novo (Ampasit) (code 4) as well as Red Caturra (code 8) and Red Bourbon (code 5) had the least similarity coefficient (0.50). Among Coffea canephora, the genetic similarity ranged from 0.57 to 0.88 . Robusta 4 (code 18) and FRT 23 (code 12) had the highest genetic similarity (0.88), while FRT 7 (code 10) and FRT 65 (code 13) were least related (0.57). Coffea liberica had genetic similarities ranging from 0.48 to 0.84 . CvSU NSIC Liberica (code 23) is the only registered Coffea liberica in the Philippines and it was closely related (0.80) to Alfonso Liberica (code 25) (Table 3, Figure 1). The planting materials were given by the Department of Agriculture (DA) (personal communication with the farmer), a government institution in the Philippines that distributes NSIC-registered varieties only. Thus, a close association of CvSU NSIC Liberica and Alfonso Liberica is expected. Although Coffea liberica is cross-pollinated, using seeds instead of a clonal method to propagate the species as practiced in the Philippines, had contributed to their dissimilarity. Coffea liberica (locally known as Kapeng Barako) has two known groups, i.e. Coffea liberica var. liberica (also known as Liberica) and Coffea liberica var. dewevrei (also known as Excelsa)
(Davis et al. 2006). The Excelsa (codes 26-29) and Liberica (codes 19-25) coffee as labeled by the farmers were grouped in a separate cluster which may indicate that they are varieties of Coffea liberica. The two varieties of Coffea liberica had no clear distinction in the PCoA, but the individuals belonging to each variety were close to each other (Figure 2).

Some studies reported a low genetic diversity of Coffea arabica. Morphological and molecular characterization of arabica cultivars in Kenya (Gichimu and Omondi 2010; Kathurima et al. 2012) and Nicaragua (Geleta et al. 2012) showed a low genetic diversity and a narrow genetic base. Teressa et al. (2010) indicated that commercial arabica cultivars were less diverse than Ethiopia's accessions. In this study, polymorphism among commercially cultivated Coffea arabica was relatively low (average genetic similarity $=0.70$ ), which may be due to its self-pollinating nature. ISSR markers generated a mean similarity coefficient of 0.68 in Coffea canephora which is close with Coffea arabica (0.70), while Coffea liberica had moderate variation (mean similarity coefficient $=0.61$ ). The low level of polymorphism in Coffea canephora supports the finding of Achar et al. (2015). Coffea liberica is naturally cross-pollinated and it is grown in the Philippines using seeds. The propagation method may have contributed to the higher genetic variation of Coffea liberica.

Table 3. Jaccard's similarity coefficients of coffee species using ISSR markers

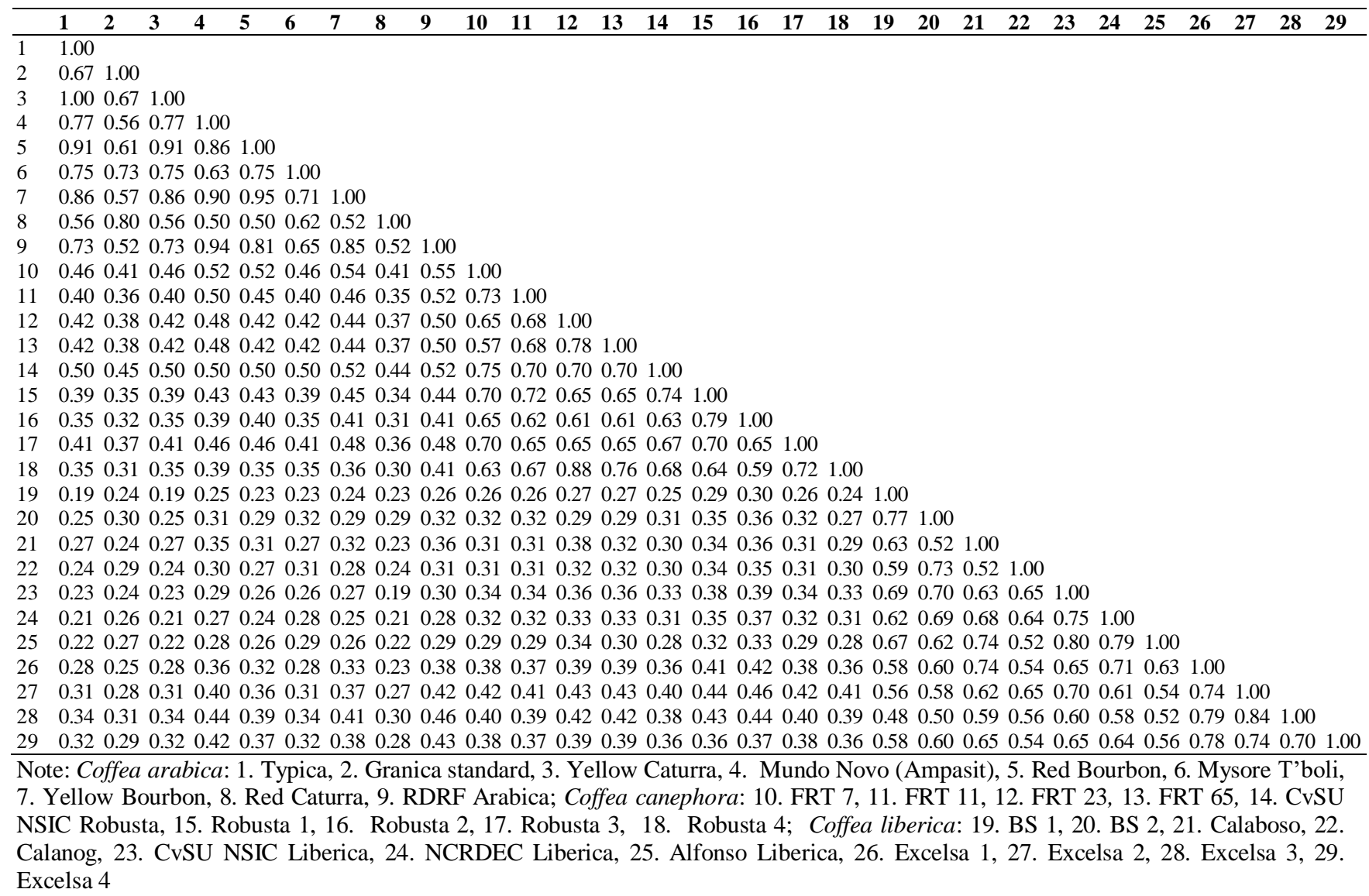




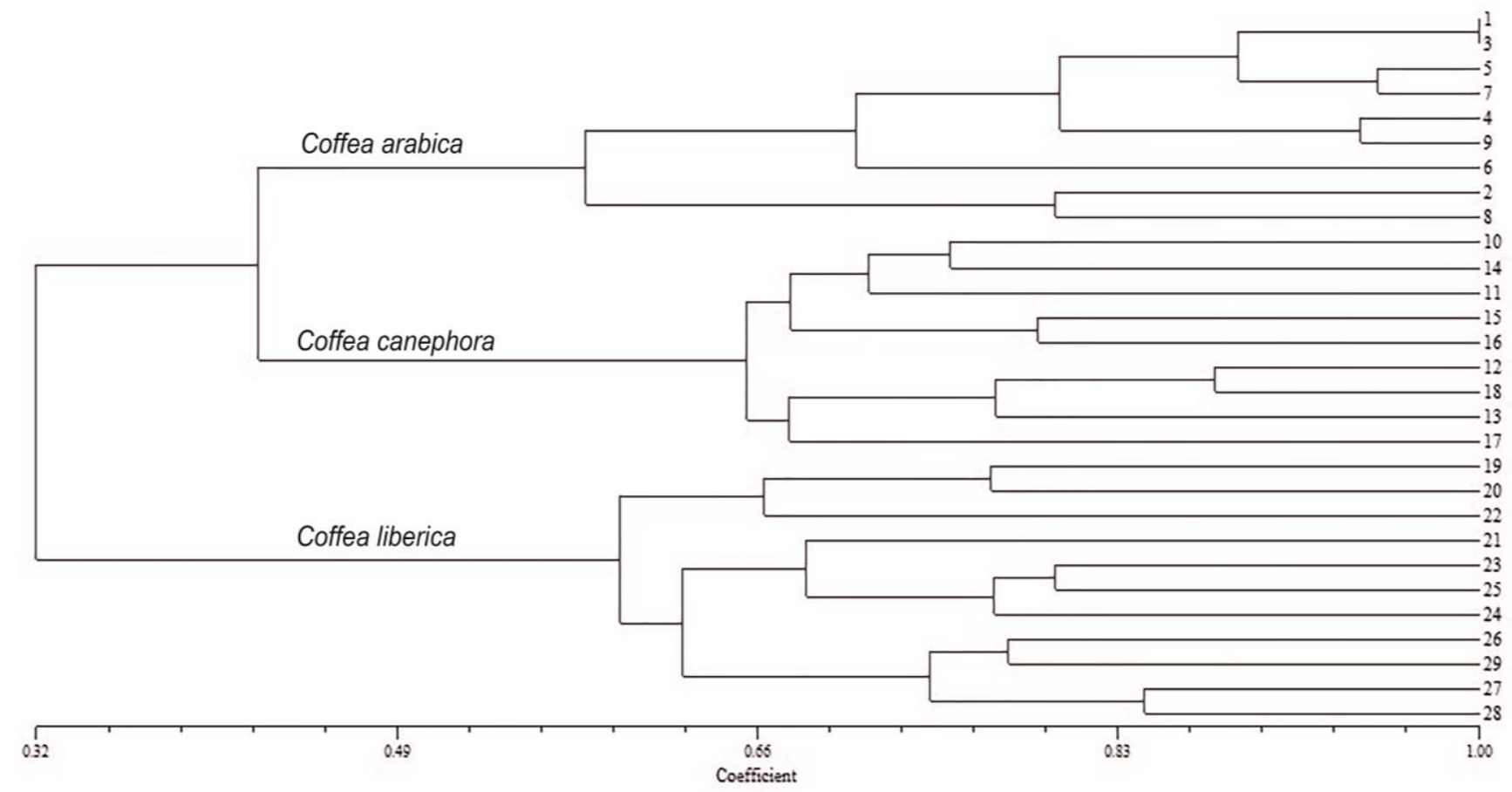

Figure 1. Dendrogram based on Jaccard similarity coefficient and UPGMA algorithm showing the genetic relationship among 29 Coffea samples analyzed using the seven ISSR markers. Coffea arabica: 1. Typica, 2. Granica standard, 3. Yellow Caturra, 4. Mundo Novo (Ampasit), 5. Red Bourbon, 6. Mysore T'boli, 7. Yellow Bourbon, 8. Red Caturra, 9. RDRF Arabica; Coffea canephora: 10. FRT 7, 11. FRT 11, 12. FRT 23, 13. FRT 65, 14. CvSU NSIC Robusta, 15. Robusta 1, 16. Robusta 2, 17. Robusta 3, 18. Robusta 4; Coffea liberica: 19. BS 1, 20. BS 2, 21. Calaboso, 22. Calanog, 23. CvSU NSIC Liberica, 24. NCRDEC Liberica, 25. Alfonso Liberica, 26. Excelsa 1, 27. Excelsa 2, 28. Excelsa 3, 29. Excelsa 4.

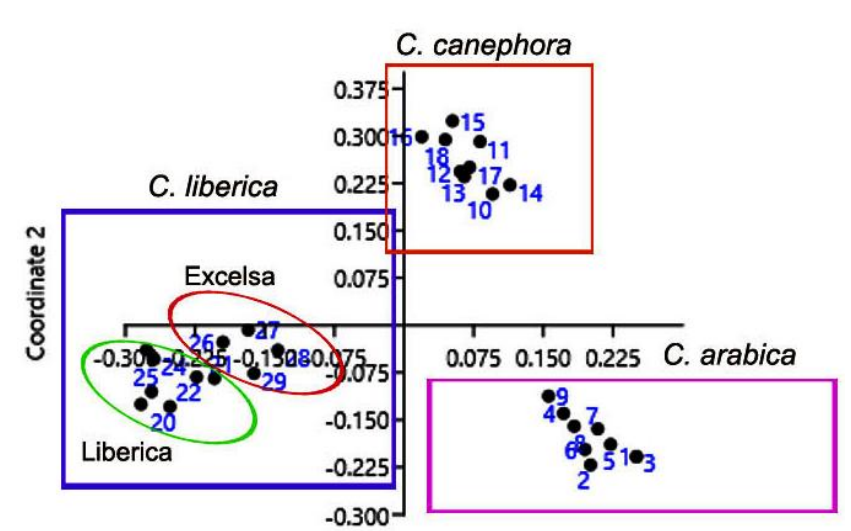

Coordinate 1

Figure 2. Relative position of 29 Coffea samples using the seven ISSR markers based on PCoA (Principal Coordinate Analysis). Coffea arabica: 1. Typica, 2. Granica standard, 3. Yellow Caturra, 4. Mundo Novo (Ampasit), 5. Red Bourbon, 6. Mysore T'boli, 7. Yellow Bourbon, 8. Red Caturra, 9. RDRF Arabica; Coffea canephora: 10. FRT 7, 11. FRT 11, 12. FRT 23, 13. FRT 65, 14. CvSU NSIC Robusta, 15. Robusta 1, 16. Robusta 2, 17. Robusta 3, 18. Robusta 4; Coffea liberica: 19. BS 1, 20. BS 2, 21. Calaboso, 22. Calanog, 23. CvSU NSIC Liberica, 24. NCRDEC Liberica, 25. Alfonso Liberica, 26. Excelsa 1, 27. Excelsa 2, 28. Excelsa 3, 29. Excelsa 4.
Interspecific differentiation among Coffea arabica (codes 1-9), Coffea canephora (codes 10-18), and Coffea liberica (codes 19-29) was evident in the cluster analysis (Figure 1). PCoA also revealed that the three Coffea species were separated, matching the cluster analysis results. The interspecific genetic similarity was low, ranging from 0.19 to 0.55 . Genetic similarity between Coffea arabica and Coffea canephora varied from 0.30 to 0.55 with an average of 0.42, Coffea canephora and Coffea liberica varied from 0.24 to 0.46 with an average of 0.35 , while Coffea liberica and Coffea arabica varied from 0.19 to 0.46 with an average of 0.29 . The mean genetic similarity revealed that Coffea arabica is closer to Coffea canephora (Figure 1). The result of this study is in line with the phylogenetic study of Davis et al. (2011) in which the internal transcribed spacer (ITS) marker showed that Coffea arabica is closer to Coffea canephora.

In conclusion, the study demonstrates the efficiency of ISSR markers to detect genetic variation in commercially cultivated coffee species in the Philippines. ISSR markers can differentiate the coffee germplasm at the interspecific level and reveal intraspecific variation. This is the first time that ISSR markers were used to determine the genetic variation of coffee cultivated in the Philippines. Furthermore, this study provides important information in breeding planning and selection programs, conservation and management strategies, and fingerprinting of elite coffee varieties. 


\section{ACKNOWLEDGEMENTS}

The authors would like to thank the Cavite State University (CvSU) - Research Center for funding this research and NCRDEC - Genetics and Tissue Culture Laboratory for providing the facilities. The first author is grateful to the Commission on Higher Education - Faculty Development Program (CHED-FDP) for the study grant.

\section{REFERENCES}

Achar AMD, Danial G, Awati M, Udayakumar M, Prasad TG. 2015. Study of genetic diversity of Coffea canephora Pierre ex A. Froehner accessions by RAPD markers. Intl J Plant Breed Genet 9 (3): 95-105. DOI: 10.3923/ijpbg.2015.95.105

Aguilera JG, Pessoni LA, Rodrigues GB, Elsayed AY, da Silva DJH, de Barros EG. 2011. Genetic variability by ISSR markers in tomato (Solanum lycopersicon Mill.). Agraria 6 (2): 243-252.

Anagbogu CF, Bhattacharjee R, Ilori C, Tongyoo P, Dada KE, Muyiwa AA, Gepts P, Beckles DM. 2019. Genetic diversity and re classification of coffee (Coffea canephora Pierre ex A. Froehner) from South Western Nigeria through genotyping-by-sequencingsingle nucleotide polymorphism analysis. Genet Resour Crop Evol 66: 685-696. DOI: 10.1007/s10722-019-00744-2.

Carrasco B, Diaz C, Moya M Gebauer M, Garcia-Gonzalez R. 2012. Genetic characterization of Japanese plum cultivars (Prunus salicina) using SSR and ISSR molecular markers. Cien Inv Agr 39 (3): 533543.

Davis AP, Govaerts R, Bridson DM, Stoffelen P. 2006. An annotated taxonomic conspectus of the genus Coffea (Rubiaceae). Bot J Linnean Soc 152: 465-512. DOI: 10.1007/s10722-019-00744-2.

Davis AP, Tosh J, Ruch N, Fay M. 2011. Growing coffee: Psilanthus (Rubiaceae) subsumed on the basis of molecular and morphological data; implications for the size, morphology, distribution and evolutionary history of Coffea. Bot J Linnean Soc 167: 357-377. DOI: 10.1111/j.1095-8339.2011.01177.x

Davis AP, Chadburn H, Moat J, O'Sullivan R, Hargreaves S, Lughadha EN. 2019. High extinction risk for wild coffee species and implications for coffee sustainability. Sci Adv 5 (1): eaav3473. DOI: 10.1126/sciadv.aav3473.

Esmailnia E, Arefrado M, Shabani S, Karimi M, Vafadar F, Dehestani A. 2015. Genetic diversity and phylogenetic relationship of Iranian indigenous cucurbits investigated by inter simple sequence repeat (ISSR) markers. Biharean Biol 9 (1): 47-54.

Ferrao LFV, Caixeta ET, Souza FDF, Zambolin EM, Cruz CD, Zambolin L, Sakiyama NS. 2013. Comparative study of different molecular markers for classifying and establishing genetic relationships in Coffea canephora. Plant Syst Evol 299: 225-238. DOI 10.1007/s00606-012-0717-2.

Garriga M, Parra PA, Peter D, Calligan S, Retamales JB, Carrasco BA, Lobos GA, Gonzales RG. 2013. Application of inter-simple sequence repeats relative to simple sequence repeats as a molecular marker system for indexing blueberry cultivars. Can J Plant Sci 93: 913-921. DOI:10.4141/CJPS2013-057.
Geleta M, Herera I, Monzon A, Bryngelsson T. 2012. Genetic diversity of arabica coffee (Coffea arabica L.) in Nicaragua as estimated by simple sequence repeat markers. Sci World J 2012: 939820. DOI: $10.1100 / 2012 / 939820$.

Gichimu BM, Omondi CO. 2010. Morphological characterization of five newly developed lines of arabica coffee as compared to commercial cultivars in Kenya. Intl J Plant Breed Genet 4 (4): 238-246.

Govindaraj M, Vetriventhan M, Srinivasan M. 2015. Importance of genetic diversity assessment in crop plants and its recent advances: An overview of its analytical perspective. Genet Res Intl 1-14. DOI: $10.1155 / 2015 / 431487$

Grativol C, Lira-Medeiros C, Hemerly AS, Ferreira PCG. 2010. High efficiency and reliability of inter-simple sequence repeats (ISSR) markers for evaluation of genetic diversity in Brazilian cultivated Jatropha curcas L. accessions. Mol Biol Rep. DOI 10.1007/s11033010-0547-7.

Hammer O, Harper DAT, Ryan PD. 2001. Past: Paleontological statistics software package for education and data analysis. Palaeontologia $\begin{array}{llll}\text { Electronica } & 4 & \text { (1). http://palaeo- }\end{array}$ electronica.org/2001_1/past/issue1_01.htm.

International Coffee Organization (ICO). 2018. Trade Statistics. Published on the Internet: http://www.ico.org/trade_statistics.asp [May 26, 2020].

Kathurima WC, Kenji GM, Muhoho SM, Bouglanger R, Gichimu BM, Gichuru EK. 2012. Genetic diversity among commercial coffee varieties, advanced selections and museum collections in Kenya using molecular markers. Intl J Biodivers Conserv 4 (2): 39-46. DOI: 10.5897/IJBC11.231.

Kayis SA, Hakki EE, Pinarkara E. 2010. Comparison of effectiveness of ISSR and RAPD markers in genetic characterization of seized marijuana (Cannabis sativa L.) in Turkey. Afr J Agric Res 5 (21): 2925-2933.

Lal S, Devmurari A, Mistry KN. 2014. Genetic diversity analysis of different varieties of Mentha piperita from Central and South Gujarat (India) through RAPD, ISSR, and SSR markers. IJBPAS 3 (1): 63 77.

Mishra MK, Nishani S, Jayarama. 2011. Genetic relationship among coffee species from India using RAPD, ISSR and SRAP markers. Biharean Biol 5 (1): 17-24.

Prevost A, Wilkinson MJ. 1999. A new system of comparing PCR primers applied to ISSR fingerprinting of potato cultivars. Theor Appl Genet 8: 107-112.

Raghavendra G, Thirumeni S, Paramasiyam K, Rettinassababady C. 2016. Genetic diversity analysis of Rice (Oryza sativa L.) varieties using ISSR markers. Intl J Sci Nat 7 (1): 98-103.

Rohlf FJ. 2000. NTSYS-PC, Numerical taxonomy, and multivariate analysis system, version 2.1. Exeter Software, New York.

Roldán-Ruiz I, Dendauw J, Bockstaele EV, Depicker A, De Loose MA. 2000. AFLP markers reveal high polymorphic rates in ryegrasses $\begin{array}{lllll}\text { (Lolium spp.). Mol Breed 6: 125-134. DOI: } & \end{array}$ 10.1023/A:1009680614564

Teressa A, Crouzillat D, Petiard V, Brouhan P. 2010. Genetic diversity of arabica coffee (Coffea arabica L.). Ethiopian J Appl Sci Technol 1 (1): 63-79.

Wahyudi D, Rifliyah K, Uslan. 2020. Genome evaluation of banana cultivars based on morphological character and inter-simple sequence repeat (ISSR) molecular marker. Biodiversitas 21 (7): 2982-2990. DOI: $10.13057 /$ biodiv/d210715. 